\title{
Preliminary study of the antioxidant properties of flowers and roots of Pyrostegia venusta (Ker Gawl) Miers
}

Purabi Roy ${ }^{1}$, Sarika Amdekar ${ }^{1}$, Avnish Kumar ${ }^{2}$ and Vinod Singh ${ }^{1 *}$

\begin{abstract}
Background: Free radical stress leads to tissue injury and can eventually to arthritis, atherosclerosis, diabetes mellitus, neurodegenerative diseases and carcinogenesis. Several studies are ongoing worldwide to find natural antioxidants of plant origin. We assessed the in-vitro antioxidant activities and screened the phytochemical constituents of methanolic extracts of Pyrostegia venusta (Ker Gawl) Miers.

Methods: We evaluated the antioxidant potential and phytochemical constituents of $P$. venusta using 1,1-Diphenyl2-picrylhydrazyl (DPPH), 2, 2'-azinobis-3-ethylbenzothiazoline-6-sulfonic acid (ABTS) and ferric reducing antioxidant power (FRAP) assays. Gas chromatography-mass spectroscopy (GC-MS) studies were also undertaken to assess the phytochemical composition of the flower extracts.

Results: Phytochemical analyses revealed the presence of terpenoids, alkaloids, tannins, steroids, and saponins. The reducing ability of both extracts was in the range (in $\mu \mathrm{m} \mathrm{Fe}(\mathrm{II}) / \mathrm{g}$ ) of 112.49-3046.98 compared with butylated hydroxytoluene (BHT; $63.56 \pm 2.62)$, catechin $(972.02 \pm 0.72 \mu \mathrm{m})$ and quercetin $3208.27 \pm 31.29$. A significant inhibitory effect of extracts of flowers $\left(I C_{50}=0.018 \pm 0.69 \mathrm{mg} / \mathrm{ml}\right)$ and roots $\left(I C_{50}=0.026 \pm 0.94 \mathrm{mg} / \mathrm{ml}\right)$ on ABTS free radicals was detected. The antioxidant activity of the extracts of flowers (95\%) and roots (94\%) on DPPH radicals was comparable with that of ascorbic acid (98.9\%) and BHT (97.6\%). GC-MS study revealed the presence of myoinositol, hexadecanoic acid, linoleic acid, palmitic acid and oleic acid in the flower extracts.

Conclusion: These data suggest that $P$. venusta is a natural source of antioxidants. The extracts of flowers and roots of $P$. venusta contain significant amounts of phytochemicals with antioxidative properties and could serve as inhibitors or scavengers of free radicals. P. venusta could be exploited as a potential source for plant-based pharmaceutical products. These results could form a sound basis for further investigation in the potential discovery of new natural bioactive compounds.
\end{abstract}

Keywords: Antioxidants, DPPH, Flavonoids, Pyrostegia venusta

\section{Background}

Oxygen is essential to many living organisms for the production of energy to fuel biological processes. However, the metabolism of oxygen generates 'free radicals' which induce oxidative damage to biomacromolecules, including DNA, proteins, membrane lipids and carbohydrates [1]. A common theme that underlies the aetiology of several degenerative disorders is free radical stress [2]. Free

\footnotetext{
* Correspondence: vsingh3@rediffmail.com

'Department of Microbiology, Barkatullah University, Hoshangabad Road,

Habibganj, Bhopal, 462024, Madhya Pradesh, India

Full list of author information is available at the end of the article
}

radicals are reported to be involved in the occurrence of numerous diseases such as cancer, diabetes mellitus, atherosclerosis, cardiovascular diseases, ageing and inflammatory diseases [3-7]. Antioxidants are vital substances because they can protect the body from the damage caused by free radicals. They exert their effect by scavenging the free radicals (i.e. reactive oxygen species (ROS) or reactive nitrogen species) universally present in biological systems [7].

There is increasing interest in the natural antioxidants (e.g. polyphenols (flavonoids and tannins)) present in plants used for medicinal and dietary purposes, which

\section{Biomed Central}


might help to prevent oxidative damage [8]. Many synthetic antioxidants (e.g. butylated hydroxyanisole (BHA)) are very effective. However, they possess certain side effects and are toxic to humans $[9,10]$. Hence, compounds (especially those from natural sources capable of protecting against ROS-mediated damage) may have potential applications in the prevention and/or cure of certain human diseases.

Pyrostegia venusta (Ker-Gawl) Miers (family, Bignoniaceae) is a neotropic evergreen vine widely distributed in southern Brazil. Native Brazilians use the aerial parts of $P$. venusta for the treatment of cough and flu. They administer its decoction orally as a general tonic and also as an infusion to treat diarrhoea, vitiligo, and jaundice [11-13]. Tonics made from the stems of this plant are useful for the treatment of diarrhoea, whereas flower preparations have been shown to attenuate vomiting [13]. Chemical investigations have shown that methanolic extracts of the roots of $P$. venusta contain allantoin, steroids, flavonone hesperidin (4,7-O-b-D-rutinosil-3',5dihydroxy-4'-methoxyiflavanona) and 3-b-b-D-glicopiranosilsitosterol [11]. Similar observations regarding the isolation of $\mathrm{n}$-hentriacontan $\left(n-\mathrm{C}_{31} \mathrm{H}_{64}\right) 7-\mathrm{O}$-b-D-glicopiranosilacacetina), meso-inositol (myo-inositol) as well as several amino acids and sugars have been observed in the flowers [13].

After careful review of the literature, the methanolic extracts of the flowers and roots of this plant were screened for antioxidant properties. Furthermore, the flower extract was chosen for gas chromatography-mass spectroscopy (GC-MS) study to justify its prominent antioxidant activity. A considerable body of research in this area is poised to provide the pharmacological basis for the development of novel treatments based upon the unique ability to selectively eliminate free radicals. If such medicinal potential was gauged correctly, then use of this plant could justify and provide a novel pathway for the treatment of diseases such as arthritis.

\section{Methods}

All chemicals and reagents used in the present study were of analytical grade. They were purchased from Sigma Life Sciences (Mumbai, India).

\section{Collection and validation of samples}

The flowers and roots of $P$. venusta were collected from Bhopal (capital of Madhya Pradesh, India). Plants were cross-identified by their vernacular names and later validated at the Department of Botany, Sarojini Naidu Government Girls P.G. College (Bhopal, India). Voucher specimens (accession number Bot./210609 and Bot./210610) were deposited for future reference in the herbarium of Sarojini Naidu Government Girls P.G. College.

\section{Processing of samples of roots and flowers}

The withered flowers and roots (250-g each) of this plant were washed vigorously with tap water to remove soil and dust. The flowers and roots were left in the shade to dry for 15-20 days. All dried material was chopped into small fragments. They were then reduced into a fine powder with a mortar and pestle. The powder could then pass through a sieve of pore size $0.5 \mathrm{~mm}$. Powdered samples were extracted at room temperature thrice with methanol for $48 \mathrm{~h}$ on an orbital shaker to make methanolic extracts $[14,15]$. Finally, the methanolic extracts were concentrated using a rota-evaporator (4001; Heidolph Instruments, Schwabach, Germany) at a reduced pressure and at $<40^{\circ} \mathrm{C}$.

\section{Phytochemical analyses}

The presence of phytochemicals such as alkaloids, saponins, tannins (5\% ferric chloride), terpenoids (2,4-dintrophenyl hydrazine) and steroids (Liebermann-Burchard test) were evaluated according to the methods described by Edeoga et al. [16].

\section{Alkaloids}

Dragendorff's reagent was prepared by mixing $0.4 \mathrm{~g}$ of bismuth subnitrate in $10 \mathrm{ml} \mathrm{HCl}(12 \mathrm{~N})$ with $5 \mathrm{~g}$ of potassium iodide in $50 \mathrm{ml}$ distilled water. Then, $0.5 \mathrm{~g}$ of the extract were stirred with $5 \mathrm{ml}$ of $1 \%$ aqueous $\mathrm{HCl}$ on a steam bath. A few drops of Dragendorff's reagent were used to treat $1 \mathrm{ml}$ of the filtrate. Orange precipitation indicated the presence of alkaloids.

\section{Steroids}

Acetic anhydride $(2 \mathrm{ml})$ was added to 0.5 -g methanolic extracts in $2 \mathrm{ml}$ of $\mathrm{H}_{2} \mathrm{SO}_{4}$. The change in colour from violet to blue or green indicated the presence of steroids.

\section{Terpenoids}

The Salkowski test was undertaken to ascertain if terpenoids were present. Five millilitres of extract were mixed in $2 \mathrm{ml}$ of chloroform and layered over $3 \mathrm{ml}$ of concentrated $\mathrm{H}_{2} \mathrm{SO}_{4}$. A reddish-brown colour of the interface demonstrated the presence of terpenoids.

\section{Tannins}

About $0.5 \mathrm{~g}$ of the dried powdered sample was boiled in $20 \mathrm{ml}$ of water and then filtered. A few drops of $0.1 \%$ ferric chloride was added to the filtrate and observed for brownish green or a blue-black colouration. Presence of tannins was further confirmed by the gelatin test. One millilitre of extract $(300 \mathrm{mg} / \mathrm{ml}$ ) was added to $2 \mathrm{ml}$ of sodium chloride (2\%), filtered and mixed with $5 \mathrm{ml}$ of $1 \%$ gelatine solution. A precipitate indicated the presence of tannins.

\section{Saponins}

The frothing test was used to check for the presence of saponins. Two grammes of the methanolic extract was mixed in $20 \mathrm{ml}$ of distilled water, boiled in a water bath, and filtered. Ten millilitres of the filtrate was taken aside, and an additional $5 \mathrm{ml}$ of distilled water added and shaken 
vigorously to generate a stable, persistent froth. Froth formation indicated the presence of saponins.

\section{In-vitro antioxidant assays \\ 1,1-Diphenyl-2-picrylhydrazyl (DPPH) radical scavenging assay}

The effect of extracts on DPPH radicals was estimated according to the method of Blois [17] with minor modifications. The methanolic extract was lyophilised and dilutions from $0.02 \mathrm{mg} / \mathrm{ml}$ to $0.1 \mathrm{mg} / \mathrm{ml}$ prepared. One millilitre $(0.135 \mathrm{mM})$ of DPPH solution was mixed with $1.0 \mathrm{ml}$ of extract (in methanol). The reaction mixture was vortex-mixed thoroughly and incubated at room temperature in the dark for $30 \mathrm{~min}$. Reduction in the absorbance of the mixture was measured at $517 \mathrm{~nm}$ using ascorbic acid as a control. Scavenging of DPPH radicals by the extract was calculated using the following formula:

Inhibition $\left.(\%)=\left[\left(\mathrm{Abs}_{\text {control }}-\mathrm{Abs}_{\text {sample }}\right)\right] /\left(\mathrm{Abs}_{\text {control }}\right)\right] \times 100$

where $\mathrm{Abs}_{\text {control }}$ is the absorbance of DPPH and Abssample is the absorbance of the DPPH radical + sample extract/standard. The half maximal inhibitory concentration $\left(\mathrm{IC}_{50}\right)$ values denoted the concentration of sample required to scavenge $50 \%$ of DPPH free radicals.

\section{2, 2'-azinobis-3-ethylbenzothiazoline-6-sulfonic acid (ABTS) radical scavenging assay}

The ABTS assay method was used as directed by the study by Re et al. [18]. ABTS solution (7 mM) and $2.4 \mathrm{mM}$ potassium persulfate (PPS) solution were mixed in equal volume and left to react for $12 \mathrm{~h}$ in the dark to prepare a working solution. One millilitre of a diluted working solution of ABTS-PPS was mixed with $1 \mathrm{ml}$ of plant extracts, and the absorbance read at $734 \mathrm{~nm}$ after 7 min. ABTS $^{++}$the scavenging capacity of the extract were compared with standard butylated hydroxytoluene (BHT). The percentage inhibition of the formation of ABTS $^{++}$was calculated using the following formula:

$$
\text { Inhibition } \left.(\%)=\left[\left(\mathrm{Abs}_{\text {control }}-\mathrm{Abs}_{\text {sample }}\right)\right] /\left(\mathrm{Abs}_{\text {control }}\right)\right] \times 100
$$

where $\mathrm{Abs}_{\text {control }}$ is the absorbance of ABTS radical + methanol and $\mathrm{Abs}_{\text {sample }}$ is the absorbance of the ABTS radical + sample extract/standard.

\section{Ferric reducing antioxidant power (FRAP) assay}

A modified method of that used by Benzie and Strain [19] was adopted for the FRAP assay. A solution of $20 \mathrm{mM} \mathrm{FeCl} \cdot 6 \mathrm{H}_{2} \mathrm{O}, 300 \mathrm{mM}$ acetate buffer $(3.1 \mathrm{~g}$ $\mathrm{C}_{2} \mathrm{H}_{3} \mathrm{NaO}_{2} \cdot 3 \mathrm{H}_{2} \mathrm{O}$ in $16 \mathrm{ml} \mathrm{C}_{2} \mathrm{H}_{4} \mathrm{O}_{2}, \mathrm{pH}$ 3.6) and $10 \mathrm{mM}$ 2,4,6-tripyridyl-s-triazine (TPTZ) in $40 \mathrm{mM} \mathrm{HCl}$ ) was prepared. At the time of establishing the assay, $25 \mathrm{ml}$ acetate buffer, $2.5 \mathrm{ml} \mathrm{TPTZ}$, and $2.5 \mathrm{ml} \mathrm{FeCl} 3 \cdot 6 \mathrm{H}_{2} \mathrm{O}$ was mixed to prepare the FRAP solution. Plant extract
$(150 \mu \mathrm{l})$ was mixed with $2850 \mu \mathrm{l}$ of FRAP solution and incubated at room temperature in the dark for $30 \mathrm{~min}$. Absorbance of the intense blue-coloured product (ferrous tripyridyltriazine complex) was measured at $593 \mathrm{~nm}$. The observed absorbance of the sample was calculated by putting the values on a linear standard curve plotted between $200 \mu \mathrm{M}$ to $1000 \mu \mathrm{M} \mathrm{FeSO}_{4}$. Results were expressed in $\mu \mathrm{M} \mathrm{Fe(II)/g} \mathrm{dry} \mathrm{mass} \mathrm{of}$ methanolic extracts of flowers and roots.

\section{GC-MS analyses of methanolic extracts of $P$. venusta}

Flower extracts of $P$. venusta were chosen for GC-MS studies due to their potent antioxidant activity. GC-MS analyses were carried out on an Agilent Technologies 7890A-GC system (Agilent Technologies, Santa Clara, CA, USA) coupled to XLMSD-5975C equipment operating in electrospray ionisation (EI) mode at $70 \mathrm{eV}$. A HP-5 MS column $(30 \mathrm{~m} \times 250 \mu \mathrm{m} \times 0.25 \mu \mathrm{m}$; Sigma-Aldrich, St Louis, MO, USA) was used. The temperature programme was $100-180^{\circ} \mathrm{C}$ at $15^{\circ} \mathrm{C} \mathrm{min}^{-1}$ and $180-300^{\circ} \mathrm{C}$ at

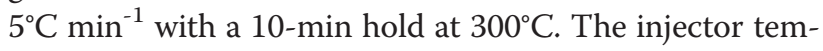
perature was $250^{\circ} \mathrm{C}$. The flow rate of the carrier gas (helium) was $1 \mathrm{ml} / \mathrm{min}$. A split ratio of $1: 5$ was used. Identification of each individual constituent of the volatile compound was achieved by comparing the retention times with those of authentic compounds as well as the spectral data obtained from the Wiley Library and National Institute of Standards and Technologies library.

\section{Statistical analyses}

Statistical analyses of results were undertaken using Statistical Analysis System software 9.2 (SAS, Cary, NC, USA). One-way analysis of variance (ANOVA) was determined using the Student's $t$ - test. Results were considered significant and very significant if $P$ values were $<0.05$ and $<0.01$, respectively. Observations were recorded in triplicate and represented as the mean \pm SD of five separate experiments.

\section{Results}

\section{Phytochemical analyses}

Phytochemical screening of the methanol extracts of the flowers and roots of $P$. venusta showed the presence of terpenoids, alkaloids, tannins, steroids, and saponins (Table 1).

\section{In-vitro antioxidant activity: inhibition of DPPH radicals}

The DPPH approach is widely applied to measure the antioxidant properties of compounds. DPPH'is an organic nitrogen radical with ultraviolet-visible absorption in the range $515-520 \mathrm{~nm}$, and the colour of its solution fades upon reduction [20]. The dose-response curve of DPPH radical scavenging activity of the methanolic extracts of the flowers and roots of $P$. venusta were compared with those of BHT and ascorbic acid (Figure 1). The flower 
Table 1 Phytochemical screening of methanol extract of flower and root of Pyrostegia venusta (Ker-Gawl.) Miers

\begin{tabular}{llll}
\hline S.No. & Constituents & \multicolumn{2}{c}{ Methanol extract } \\
& & Flower & Root \\
\hline 1 & Alkaloids & & \\
& $\cdot$ Dragendorf's test & ++ & ++ \\
\hline 2 & Terpenes and steroids & & \\
& $\cdot$ Salkowski test & ++ & ++ \\
& $\cdot$ Libarman- Burchard's test & ++ & ++ \\
\hline 3 & Tannins & & \\
& $\cdot$ FeCl test & ++ & ++ \\
& $\cdot$ Gelatin test & ++ & ++ \\
\hline 4 & Saponins & - & ++ \\
& • Frothing test & & \\
\hline
\end{tabular}

Key:- = Negative (absent)

$++=$ Positive (present)

extracts almost identical free-radical scavenging activity (95\%) as those of the roots $(94 \%)$ at $0.1 \mathrm{mg} / \mathrm{ml}$. The scavenging activity of controls (ascorbic acid and BHT) was $98.9 \%$ and $97.6 \%$, respectively. The $\mathrm{IC}_{50}$ values obtained for flowers and roots were $0.026 \pm 0.41 \mathrm{mg} / \mathrm{ml}$ and $0.034 \pm 0.52 \mathrm{mg} / \mathrm{ml}$, and for ascorbic acid and BHT were $0.014 \pm 0.66 \mathrm{mg} / \mathrm{ml}$ and $0.029 \pm 0.35 \mathrm{mg} / \mathrm{ml}$, respectively.

\section{ABTS radical scavenging assay}

ABTS oxidized with PPS (absorption maxima at 734 $\mathrm{nm}$ ) leads to the generation of ABTS free radicals. This method is based on the ability of antioxidants to quench the $\mathrm{ABTS}^{++}$radical cation [18]. Methanol extracts of the flowers and roots of $P$. venusta were rapid and effective scavengers of the ABTS radical (Figure 2) and this activity was comparable with that of BHT. At $0.1 \mathrm{mg} / \mathrm{ml}$, the

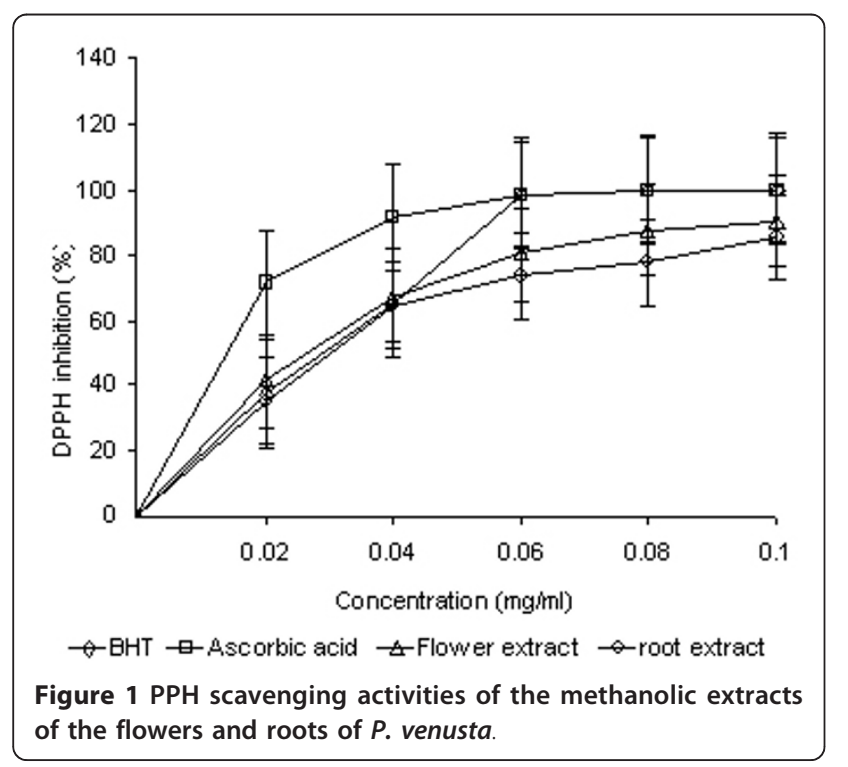

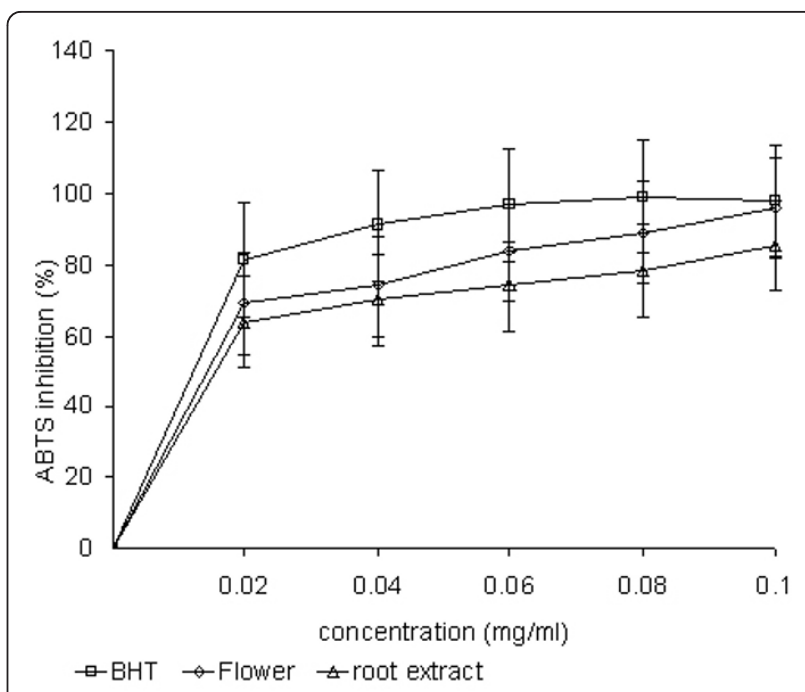

Figure 2 ABTS activities of the methanolic extracts of the flowers and roots of $P$. venusta.

percentage inhibition was $98 \%$ for BHT, $96 \%$ for flower extracts, and $85 \%$ for root extracts. The $\mathrm{IC}_{50}$ value for BHT, flowers, and roots were $0.012 \pm 0.33 \mathrm{mg} / \mathrm{ml}$, $0.018 \pm 0.69 \mathrm{mg} / \mathrm{ml}$ and $0.026 \pm 0.94 \mathrm{mg} / \mathrm{ml}$, respectively. The relative reducing power of all the extracts was in the order: BHT > flower extracts > root extracts.

\section{FRAP assay}

The FRAP assay can be used to assess the antioxidant potential in the extracts of flowers and roots of $P$. venusta by showing their ability to reduce the TPTZ-Fe(III) complex to TPTZ-Fe(II). The reducing ability of root extracts $(3046.98 \pm 60.87 \mu \mathrm{m} \mathrm{Fe}(\mathrm{II}) / \mathrm{g})$ were close to that of quercetin $(3208.27 \pm 31.29 \mu \mathrm{m} \mathrm{Fe}(\mathrm{II}) / \mathrm{g})$, which is the most researched type of flavonoid. The reducing ability of flower extracts was $112.49 \pm 37.11 \mu \mathrm{m} \mathrm{Fe}(\mathrm{II}) / \mathrm{g}$ (Table 2).

\section{GC-MS study}

The GC-MS study indicated that the phytochemicals myoinositol, hexadecanoic acid, linoleic acid, oleic acid, stigmasteryl tosylate, diazoprogesterone, arabipyranose,

Table 2 Total antioxidant activity of the methanolic extracts of the flowers and roots of Pyrostegia venusta (Ker-Gawl.) Miers

\begin{tabular}{ll}
\hline Extracts & FRAP \\
\hline Flowers & $112.49 \pm 37.11$ \\
\hline Root & $3046.98 \pm 60.87$ \\
\hline Ascorbic acid & $1632.1 \pm 16.71$ \\
\hline BHT & $63.56 \pm 2.62$ \\
\hline Catechin & $972.02 \pm 0.72$ \\
\hline Quercetin & $3208.27 \pm 31.29$ \\
\hline
\end{tabular}


Table 3 Phytocomponents identified in the methanolic extract of flowers of Pyrostegia venusta by GC-MS

\begin{tabular}{|c|c|c|c|c|}
\hline RT & Name of Compound & Molecular & MW & $\begin{array}{l}\text { Peak Area } \\
\text { (\%) }\end{array}$ \\
\hline 5.478 & Acetophenone & $\mathrm{C}_{8} \mathrm{H}_{8} \mathrm{O}$ & 120.058 & 0.325 \\
\hline 11.032 & .alpha.-I-Mannopyranoside, methyl 6-deoxy-2,3,4-tris-O-(trimethylsilyl)- & $\mathrm{C}_{30} \mathrm{H}_{70} \mathrm{O}_{9} \mathrm{Si}_{6}$ & 394.203 & 4.952 \\
\hline 11.295 & $\begin{array}{l}\text { 3H-3a,7-Methanoazulene, 2,4,5,6,7,8-hexahydro-1,4,9,9-tetramethyl-, [3aR-(3a.alpha.,4.beta.,7.alpha.)]- } \\
\text { (Synonym Cyperene) }\end{array}$ & $\mathrm{C}_{15} \mathrm{H}_{24}$ & 204.188 & 0.101 \\
\hline 15.473 & trans-3-Hexenedioic acid, bis(trimethylsilyl) ester & $\mathrm{C}_{12} \mathrm{H}_{24} \mathrm{O}_{4} \mathrm{Si}_{2}$ & 288.121 & 0.914 \\
\hline 15.878 & beta.-DL-Arabinopyranose, 1,2,3,4-tetrakis- O-(trimethylsilyl)- (Synonym- B Arabipyranos & $\mathrm{C}_{17} \mathrm{H}_{42} \mathrm{O}_{5} \mathrm{Si}_{4}$ & 438.211 & 2.498 \\
\hline 16.072 & Ethylmalonate, ethyltrimethylsilyl ester & $\mathrm{C}_{8} \mathrm{H}_{16} \mathrm{O}_{4} \mathrm{Si}$ & 232.113 & 2.311 \\
\hline 16.402 & Propionic acid, pentamethyldidilanyl ester & $\mathrm{C}_{8} \mathrm{H}_{20} \mathrm{O}_{2} \mathrm{Si}_{2}$ & 204.1 & 0.519 \\
\hline 18.315 & Glycoside, .alpha.-methyl-trtrakis-O-(trimethylsilyl)- & & 482.237 & 11.713 \\
\hline 18.596 & Hexadecanoic acid, methyl ester (Synonym-Palmitic Acid) & $\mathrm{C}_{17} \mathrm{H}_{34} \mathrm{O}_{2}$ & 274.196 & 5.394 \\
\hline 18.688 & D-Xylose, tetrakis(trimethylsilyl)- & $\mathrm{C}_{18} \mathrm{H}_{45} \mathrm{NO}_{5} \mathrm{Si}_{4}$ & 438.211 & 0.618 \\
\hline 18.838 & Glycoside,.alpha.-methyl-trtrakis-O-(trimethylsilyl)- & $\mathrm{C}_{19} \mathrm{H}_{46} \mathrm{O}_{6} \mathrm{Si}_{4}$ & 482.237 & 7.364 \\
\hline 19.806 & Gluconic acid, 2-methoxime, tetra(trimethylsilyl)-, trimethylsilyl ester & & 583.267 & 1.503 \\
\hline 23.174 & 9,12-Octadecadienoic acid, methyl ester (Synonym Linoleic acid) & $\mathrm{C}_{19} \mathrm{H}_{34} \mathrm{O}_{2}$ & 294.256 & 4.225 \\
\hline 23.346 & 9-Octadecenoic acid (Z)-, methyl ester (Synonym OleicAcid) & $\mathrm{C}_{19} \mathrm{H}_{36} \mathrm{O}_{2}$ & 296.272 & 5.606 \\
\hline 24.118 & Myo-Inositol, 1,2,3,4,5,6-hexakis-O-(trimethylsilyl)- & $\mathrm{C}_{24} \mathrm{H}_{60} \mathrm{O}_{6} \mathrm{Si}_{6}$ & 612.301 & 33.033 \\
\hline 31.17 & Docosanoic acid, methyl ester (Synonym Hysterene) & $\mathrm{C}_{23} \mathrm{H}_{46} \mathrm{O}_{2}$ & 354.35 & 0.709 \\
\hline 31.291 & 1,2-Benzenedicarboxylic acid, mono(2-ethylhexyl) ester (Synonym Pthalic Acid) & $\mathrm{C}_{16} \mathrm{H}_{22} \mathrm{O}_{4}$ & 278.152 & 0.454 \\
\hline 31.712 & Methyl 10-methyl-undecanoate & $\mathrm{C}_{13} \mathrm{H}_{26} \mathrm{O}_{2}$ & 214.193 & 0.12 \\
\hline 31.873 & {$[1,2,4]$ Triazolo[1,5-a]pyrimidine-6-carboxylic acid, 4,7-dihydro-7-imino-, ethyl ester } & & 207.076 & 0.124 \\
\hline 32.064 & Dotriacontane & $\mathrm{C}_{32} \mathrm{H}_{66}$ & 450.516 & 0.402 \\
\hline 32.179 & Silicic acid, diethyl bis(trimethylsilyl) ester & $\mathrm{C}_{10} \mathrm{H}_{28} \mathrm{O}_{4} \mathrm{Si}_{3}$ & 296.13 & 0.074 \\
\hline 32.237 & Tetracosanoic acid, methyl ester & $\mathrm{C}_{25} \mathrm{H}_{50} \mathrm{O}_{2}$ & 382.381 & 1.12 \\
\hline 32.59 & Di-n-decylsulfone & $\mathrm{C}_{20} \mathrm{H}_{42} \mathrm{O}_{2} \mathrm{~S}$ & 346.291 & 0.101 \\
\hline 32.984 & Dodecahydropyrido[1,2-b]isoquinolin-6-one & $\mathrm{C}_{13} \mathrm{H}_{21} \mathrm{~N}$ & 207.162 & 0.163 \\
\hline 33.159 & Heptacosane & $\mathrm{C}_{27} \mathrm{H}_{56}$ & 380.438 & 3.202 \\
\hline 33.264 & Tetrasiloxane, decamethyl- & $\mathrm{C}_{10} \mathrm{H}_{30} \mathrm{O}_{3} \mathrm{Si}_{4}$ & 310.127 & 0.252 \\
\hline 33.367 & Tetradecanoic acid, 12-methyl-, methyl ester & $\mathrm{C}_{16} \mathrm{H}_{32} \mathrm{O}_{2}$ & 256.24 & 0.18 \\
\hline 34.388 & Stigmasteryl tosylate & $\mathrm{C}_{29} \mathrm{H}_{48} \mathrm{O}$ & 566.379 & 1.493 \\
\hline 34.857 & 2-p-Nitrophenyl-oxadiazol-1,3,4-one-5 & $\mathrm{C}_{8} \mathrm{H}_{5} \mathrm{~N}_{3} \mathrm{O}_{4}$ & 207.028 & 0.408 \\
\hline 35.813 & 2-Methyl-6-(5-methyl-2-thiazolin-2-ylamino)pyridine & $\mathrm{C}_{10} \mathrm{H}_{13} \mathrm{~N}_{3} \mathrm{~S}$ & 208.146 & 0.623 \\
\hline 36.418 & Diazoprogesterone & $\mathrm{C}_{21} \mathrm{H}_{30} \mathrm{~N}_{4}$ & 338.247 & 1.511 \\
\hline 36.724 & 1,6-Dibromo-2-cyclohexylpentane & $\mathrm{C}_{11} \mathrm{H}_{20} \mathrm{Br}_{2}$ & 309.993 & 4.622 \\
\hline 37.079 & Cyclotrisiloxane, hexamethyl- & $\mathrm{C}_{6} \mathrm{H}_{18} \mathrm{Si}_{3}$ & 222.056 & 0.261 \\
\hline 37.409 & cis-2-Hexen-1-ol, trimethylsilyl ether & $\mathrm{C}_{6} \mathrm{H}_{12} \mathrm{O}$ & 172.128 & 1.308 \\
\hline
\end{tabular}

propanoic acid, pentamethyldisilanyl ester, acetophenone, trans-3-Hexenedioic acid, and 9-Octadecenoic acid (Z)-methyl ester (Table 3 and Figure 3) were in the flower extracts.

\section{Discussion}

Interest in finding naturally occurring antioxidants for use in foods or medicinal materials to prevent free-radical imbalance has increased considerably over the past few years [21]. Use of synthetic antioxidants such as butylated hydroxyanisole (BHA) and BHT is restricted due to their carcinogenicity [21]. Therefore, the need for identifying alternate, natural and safe sources of antioxidants (especially of plant origin) has increased in recent years [22]. The therapeutic benefits of secondary metabolites of plant origin have been researched in several recent studies [23]. The past decade has seen considerable changes in the opinion regarding the applications of ethnopharmacological therapeutics.

In the present study, $P$. venusta was assessed for its antioxidant potential using DPPH, ABTS and FRAP assays. This is the first time that this has been carried out. 


\section{Abundance}

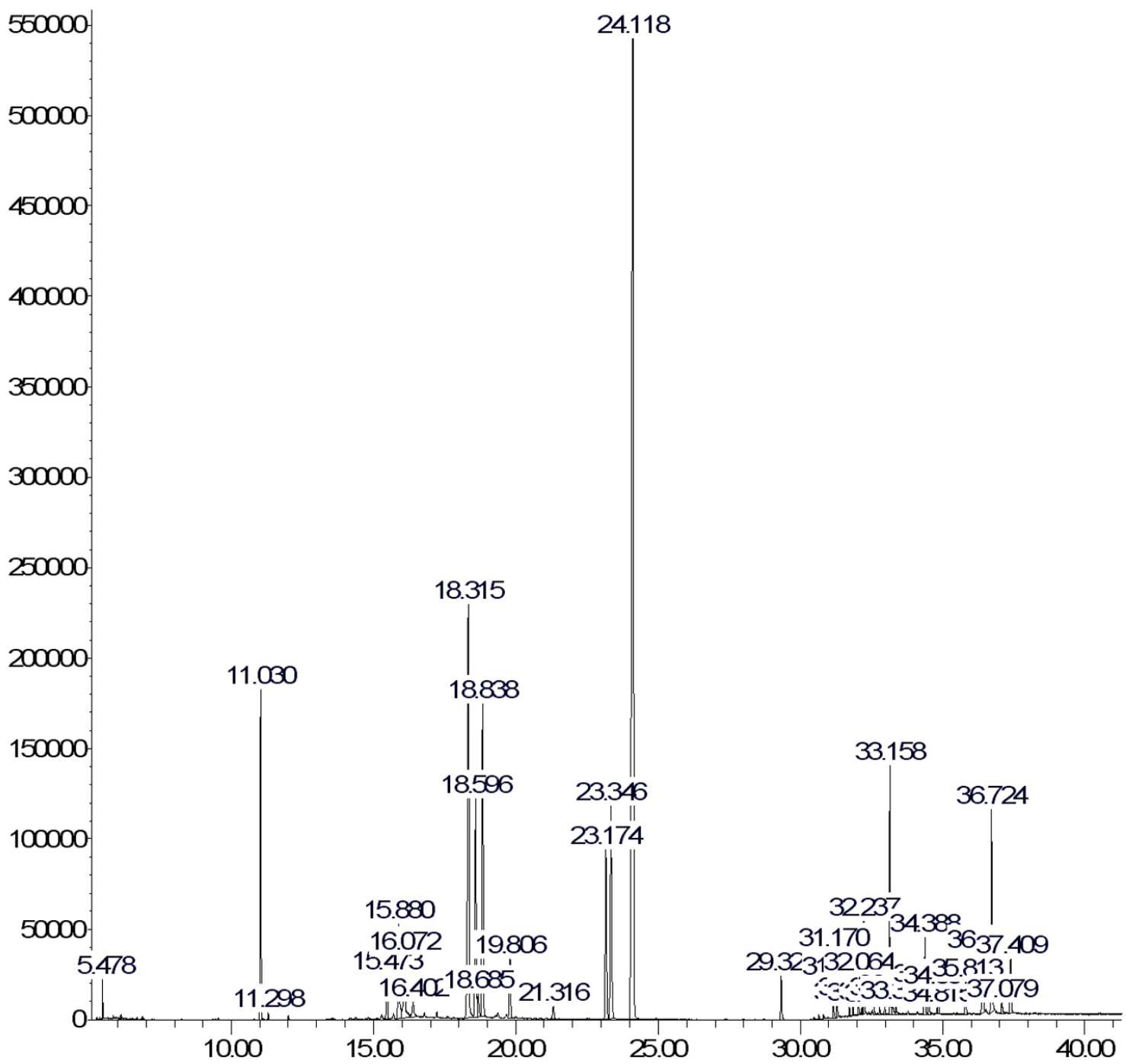

Time->

Figure 3 Chromatogram obtained from GC-MS with the methanolic extracts of the flowers of $P$. venusta

Phytochemical analyses of $P$. venusta extracts revealed the presence of terpenoids, alkaloids, tannins, steroids, and saponins. All of these compounds have been shown to be potent antioxidants $[24,25]$.

Terpenoids have been reported to have anti-inflammatory, antioxidant and neuroprotective activities [26]. Saponins and tannins are known to have analgesic and anti-inflammatory properties [27]. Tannins and saponins appear to have considerable cancer-prevention properties [28]. Alkaloid-containing plants have been used by humans for centuries for therapeutic and recreational purposes. They are known for their antimalarial, antimicrobial and cytotoxic activities [29]. Cytotoxic compounds are potentially interesting on their own or as lead compounds for the development of new anti-cancer drugs as well as drugs against parasites and viral infections. $P$. venusta containing these compounds may serve as a potential source of bioactive compounds in the prevention or cure of free radical-based disorders.

The DPPH test provided information about the reactivity of the tested compounds with a stable free radical. Because of its extra electron, the DPPH radical gives a strong absorption band at $517 \mathrm{~nm}$ under visible spectroscopy (a deep purple colour), which vanishes in the 
Table 4 Phyto-components and its biological activities obtained through the GC/MS Study of Pyrostegia venusta

\begin{tabular}{|c|c|c|}
\hline RT & Name of compound & Active biological activity** \\
\hline 5.478 & Acetophenone & Antibacterial, fingicide,pesticide, hypnotic, perfimery,sporofic \\
\hline 11.295 & $\begin{array}{l}\text { 3H-3a,7-Methanoazulene, 2,4,5,6,7,8-hexahydro-1,4,9,9- } \\
\text { tetramethyl-, [3aR-(3a.alpha.,4.beta., 7.alpha.)]-(Cyperene) }\end{array}$ & Antimalarial and Antiplasmodial \\
\hline 15.473 & Hexadecanoic acid, methyl ester (Synonym-Palmitic Acid) & $\begin{array}{l}\text { Antioxidant, hypocholesterolemic nematicide, pesticide, anti-androgenic flavor, } \\
\text { hemolytic, 5- Alpha reductase inhibitor }\end{array}$ \\
\hline 23.174 & $\begin{array}{l}\text { 9,12-Octadecadienoic acid, methyl ester (Synonym-Linoleic } \\
\text { acid) }\end{array}$ & $\begin{array}{l}\text { Antiinflammatory, hypocholesterolemic cancer preventive, hepatoprotective, } \\
\text { nematicide, insectifuge, antihistaminic antieczemic, antiacne, 5-Alpha reductase } \\
\text { inhibitor, antiandrogenic, antiarthritic, anticoronary, insectifuge }\end{array}$ \\
\hline 31.291 & $\begin{array}{l}\text { 1,2-Benzenedicarboxylic acid, mono (2-ethylhexyl) ester } \\
\text { (Synonym- Pthalic Acid) }\end{array}$ & $\begin{array}{l}\text { Used in preparation of perfumes and cosmetics, Used as plasticized vinyl seats } \\
\text { on furniture and in cars, and clothing including jackets, raincoats and boots. } \\
\text { Used in textiles, as dyestuffs, cosmetics and glass making. }\end{array}$ \\
\hline 24.118 & Myo-Inositol, 1,2,3,4,5,6-hexakis-O-(trimethylsilyl)- & Antidepression, Liver problems, panic disorders and diabetes \\
\hline 23.346 & 9-Octadecenoic acid (Z)-, methyl ester & $\begin{array}{l}\text { 5-Alpha-Reductase-Inhibitor, Allergenic, Alpha- Reductase-Inhibitor, Anemiagenic, } \\
\text { Antialopecic, Antiandrogenic, Antiinflammatory, Antileukotriene-D4 (Anti-platelet } \\
\text { activating factor), Dermatitigenic Insectifuge Perfumery, Propecic Cancer- } \\
\text { Preventive, Choleretic, Flavor, Hypocholesterolemic, Irritant, Percutaneostimulant }\end{array}$ \\
\hline 34.388 & Stigmasteryl tosylate & $\begin{array}{l}\text { Antihepatotoxic, Antiinflammmatory, Antiophidic,Antioxidant, Artemecide, } \\
\text { Extrogenic, Sedative }\end{array}$ \\
\hline
\end{tabular}

**Activity source: Dr. Duke's Phytochemical and Ethnobotanical Database.

presence of a free-radical scavenger. DPPH is usually employed as a reagent to evaluate the free-radical scavenging activity of antioxidants [30]. In the DPPH'assay, antioxidants could reduce the stable radical DPPH'to the yellow-coloured DPPH. This suggests that the plant extracts contained compounds capable of donating hydrogen to a free radical to remove the extra electron (which is responsible for the activity of free radicals).

Proton-radical scavenging is an important attribute of antioxidants [31]. The protonated radical ABTS has characteristic absorbance maxima at $734 \mathrm{~nm}$, which decreases with the scavenging of proton radicals [31]. The scavenging activity of the ABTS radical by the plant extracts was found to be appreciable. This implies that the plant extracts may be useful for treating free radical-related pathological damage (especially at a higher concentration).

The FRAP assay measures the reducing ability of antioxidants against the oxidative effects of ROS. The reducing potentials of the methanolic extracts of the flowers and roots of $P$. venusta were estimated from their ability to reduce the TPTZ-Fe(III) complex to the TPTZ-Fe(II) complex.

Assays such as ABTS, FRAP and DPPH have shown that plant extracts may be useful for treating free radical-related pathological damage [21].

In the present study, the flowers of $P$. venusta were subjected to phytochemical evaluation and GC-MS analyses but the compounds responsible for the antioxidant activity need to be explored. GC-MS analyses revealed the presence of myoinositol, hexadecanoic acid, linoleic acid, oleic acid, stigmasteryl tosylate, diazoprogesterone, arabipyranose, propanoic acid, pentamethyldisilanyl ester, acetophenone, trans-3-Hexenedioic acid, and 9- octadecenoic acid (Z)-methyl ester. These phytochemicals have been shown to possess antimicrobial, anticancer, hypercholesterolaemic and anti-ulcerogenic activities (Table 4) [32,33]. The current pioneering study suggests that this extract is a potent therapeutic agent. It paves the way for the development of several treatment regimens based on this extract. In addition, research is continuing to identify and purify the active compounds responsible for antioxidant activity.

\section{Conclusion}

The present study confirmed the in-vitro antioxidant potential of $P$. venusta, with results comparable with those of standard compounds such as ascorbic acid and BHT. These data further support the view that the flowers and roots of $P$. venusta are promising sources of natural antioxidants, and could be seen as potential sources of useful drugs. Nonetheless, further in-vivo studies and purification of the compounds responsible for antioxidant activity are needed.

\section{Acknowledgements}

The authors are grateful to the Research Fund of Barkatullah University (Bhopal, India) for laboratory support.

\section{Author details}

'Department of Microbiology, Barkatullah University, Hoshangabad Road, Habibganj, Bhopal, 462024, Madhya Pradesh, India. 'Department of Biotechnology, School of Life Sciences, Dr. B. R. Ambedkar University, Agra282002, Uttar Pradesh, India.

\section{Authors' contributions}

VS designed the work. PR, SA and AK were responsible for preparation of the extracts, phytochemical study and in-vitro antioxidation methods. All the authors approved the final manuscript. 


\section{Competing interests}

The authors declare that they have no competing interests.

Received: 22 April 2011 Accepted: 23 August 2011

Published: 23 August 2011

\section{References}

1. Aiyegoro OA, Okoh Al: Preliminary phytochemical screening and In vitro antioxidant activities of the aqueous extract of Helichrysum longifolium DC. BMC Complementary and Alternative Medicine 2010, 10:21-28.

2. Halliwell B, Gutteridge JMC, Cross CE: Free radicals, antioxidants and human disease. Lab Clin Med 1992, 119:598-620.

3. Di Matteo V, Esposito E: Biochemical and therapeutic effects of antioxidants in the treatment of Alzheimer's disease, Parkinson's disease, and amyotrophic lateral sclerosis. Curr Drug target CNS Neurological Disorders 2003, 2:95-107.

4. Geber M, Boutron-Ruault MC, Hercberg S, Riboli E, Scalbert A, Siess MH: Food and cancer: state of the art about the protective effect of fruits and vegetables. Bull Cancer 2002, 89:293-312.

5. Kris-Etherton PM, Hecker KD, Bonanome A, Coval SM, Binkosi A, Hilpert KF: Bioactive compounds in foods: their role in the prevention of cardiovascular disease and cancer. Amer J Med 2002, 113:71S-88S.

6. Serafini M, Bellocco R, Wolk A, Ekstrom AM: Total antioxidant potential of fruit and vegetables and risk of gastric cancer. Gastroenterol 2002, 123:985-991.

7. Wilson RL: Free radicals and tissue damage, mechanistic evidence from radiation studies. Biochemical mechanisms of liver injury Academy Press, New York; 1988, 123.

8. Ames BN, Gold LS, Willet WC: The causes and prevention of cancer. Proc Natl Acad Sci USA 1995, 92:5258-5265.

9. Gülçin I, Bursa E, Şehitoğlu MH, Bilsel M, Gören AC: Polyphenol contents and antioxidant activity of lyophilized aqueous extract of propolis from Erzurum, Turkey. Food and Chemical Technology 2010, 48:2227-2238.

10. Gülçin I, Topal F, Çakmakçı R, Bilsel M, Gören AC, Erdogan U: Pomological Features, Nutritional Quality, Polyphenol Content Analysis, and Antioxidant Properties of Domesticated and 3 Wild Ecotype Forms of Raspberries (Rubus idaeus L.). Journal of Food Sciences 2011, 76:585-593.

11. Ferreira DT, Alvares PS, Houghton PJ, Braz-Filho R: Chemical constituents from roots of Pyrostegia venusta and considerations about its medicinal importance. Química Nova 2000, 23:42-46.

12. Scalon SP, Vieira MC, Lima AA, Souza CM, Mussury RM: Pregerminative treatments and incubation temperatures on the germination of "cipóde-São-João" [Pyrostegia venusta (Ker Gawl.) Miers]-Bignoniaceae. Revista Brasileirade Plantas Medicinais 2008, 10:37-42.

13. Velosoa CC, Bitencourta AD, Cabral LD, Franqui LS, Dias DF, dos Santos MH, Soncini R, Giusti-Paiva A: Pyrostegia venusta attenuate the sickness behavior induced by lipopolysaccharide in mice. Journal of Ethnopharmacology 2010, 132:355-358.

14. Gülçin I, Kireçci E, Akkemik E, Topal F, Hisar O: Antioxidant and antimicrobial activities of an aquatic plant: Duckweed (Lemna minor L.). Turkish Journal of Biology 2010, 34:175-188.

15. Tohma HS, Gülçin I: Antioxidant and radical scavenging activity of aerial parts and roots of Turkish liquorice (Glycyrrhiza glabra L.). International Journal of Food Properties 2010, 13:657-671.

16. Edeogal HO, Okwu DE, Mbaebie BO: Phytochemical constituents of some Nigerian medicinal plants. African Journal of Biotechnology 2005, 7:685-688.

17. Blois MS: Antioxidant determination by the use of a stable free radical. Nature 1958, 181:1199-1200.

18. Re R, Pellegrini N, Proteggente A, Pannala A, Yang M, Rice-Evans CA: Antioxidant activity applying an improved ABTS radical cation decolorization assay. Free Radical Bio Med 1999, 26:1231-1237.

19. Benzie IFF, Strain JJ: The ferric reducing ability of plasma (FRAP) as a measure of "antioxidant power": the FRAP assay. Anal Biochem 1996, 239:70-76.

20. Gülçin I: Antioxidant properties of resveratrol: A structure-activity insight. Innovative Food Science and Emerging Technologies 2010, 11:210-218.

21. Mahdavi DL, Salunkhe DK: Toxicological aspects of food antioxidant. In Food Antioxidants. Edited by: Mahdavi DL, Deshpande SS, Salunkhe DK. New York: Marcel Dekker; 1995:267-293.
22. Zainol MK, Abd-Hamid A, Yusof S, Muse R: Antioxidant activity and total phenolic compounds of leaf, root and petiole of four accessions of Centella asiatica (L.) Urban. Food Chem 2003, 81:575-81.

23. Nayak BS, Lexley MPP: Catharanthus roseus flower extract has wound healing activity in Sprague Dawley rats. BMC Complementary and Alternative Medicine 2010, 10:21-28.

24. Hafidh RR, Abdulamir A, Bakar A, Abas F, Jahanshiri F, Sekawi Z: Antioxidant Research in Asia in the Period from 2000-2008. American Journal of Pharmacology and Toxicology 2009, 4(3):48-66.

25. Anchana Chanwitheesuk, Aphiwat Teerawutgulrag, Nuansri Rakariyatham: Screening of antioxidant activity and antioxidant compounds of some edible plants of Thailand. Food Chemistry 2005, 92:491-497.

26. Lingli Mu, Junping Kou, Danni Zhu, Boyang Yu: Comparison of Neuroprotective Effects of Flavonoids, Terpenoids, and Their Combinations from Ginkgo bilobaon Ischemia-Reperfusion-Injured Mice. Pharmaceutical Biology 2007, 45:728-733.

27. Lai FR, Wen QB, Li L, Wu H, Li XF: Antioxidant activities of water-soluble polysaccharide extracted from mung bean (Vigna radiata L.) hull with ultrasonic assisted treatment. Carbohyd Polym 2010, 81(2):323-329.

28. Sur P, Chaudhuri T, Vedasiromoni JR, Gomes A, Ganguly DK: Antiinflamatory and antioxidant property of saponins of tea [Camellia sinensis(L)O. Kuntze] root extract. Phytotherapy Reserach 2001, 15:174-176.

29. Oloyede KG, Oke MJ, Raji Y, Olugbade AT: Antioxidant and Anticonvulsant Alkaloids in Crinum ornatum bulb Extract. World journal of chemistry 2010, 5(1):26-31.

30. Krishnaraju AV, Rao CV, Rao VN, Reddy KN, Trimurtulu G: In vitro and In vivo Antioxidant Activity of Aphanamixis polystachya Bark. Americal Journal of Infectious Diseases 2009, 2:60-67.

31. Thaiponga K, Boonprakoba U, Crosbyb K, Cisneros-Zevallosc L. Byrnec DH: Comparison of ABTS, DPPH, FRAP, and ORAC assays for estimating antioxidant activity from guava fruit extracts. Journal of Food Composition and Analysis 2006, 19:669-675.

32. Sakthivel K, Palani S, Santhosh Kalash, Devi K, Senthil Kumar B: Phytoconstituents analysis by GC-MS, cardioprotective and antioxidant activity of Buchanania axillaris against Doxorubicin-Induced cardio toxicity in albino rats. International Journal of Pharmaceutical Studies and Research 2010, 1:34-48.

33. Valko M, Leibfritz D, Moncola J, Cronin MD, Mazura M, Telser J: Free radicals and antioxidants in normal physiological functions and human disease. Review Int J Biochem Cell Biol 2007, 39:44-84.

\section{Pre-publication history}

The pre-publication history for this paper can be accessed here: http://www.biomedcentral.com/1472-6882/11/69/prepub

\section{doi:10.1186/1472-6882-11-69}

Cite this article as: Roy et al.: Preliminary study of the antioxidant properties of flowers and roots of Pyrostegia venusta (Ker Gawl) Miers. BMC Complementary and Alternative Medicine 2011 11:69.

\section{Submit your next manuscript to BioMed Central and take full advantage of:}

- Convenient online submission

- Thorough peer review

- No space constraints or color figure charges

- Immediate publication on acceptance

- Inclusion in PubMed, CAS, Scopus and Google Scholar

- Research which is freely available for redistribution

Submit your manuscript at www.biomedcentral.com/submit
C Biomed Central 